\title{
Modern parameters of caesium-137 root uptake in natural and agricultural grass ecosystems of contaminated post- Chernobyl landscape, Russia
}

\author{
Tatiana Paramonova *, Ekaterina Machaeva, Vladimir Belyaev
}

Moscow State University, Soil Science Faculty, Department of Radioecology \& Ecotoxicology, Moscow, Russia

\begin{abstract}
The estimation of modern parameters of ${ }^{137}$ Cs root uptake was conducted in natural meadow and agricultural ecosystems of post-Chernobyl landscapes of Tula region. The agrosystems with main crops of field rotation (barley, potatoes, rape, maize) occupying watersheds and slopes with arable chernozems are contaminated at a level $460-670 \mathrm{~Bq} / \mathrm{kg}\left(4.7-6.0 \mathrm{Ci} / \mathrm{km}^{2}\right)$; natural meadow ecosystems occupying lower parts of slopes and floodplains are contaminated at a level 620-710 $\mathrm{Bq} / \mathrm{kg}\left(5.8-7.6 \mathrm{Ci} / \mathrm{km}^{2}\right)$. In the arable soils ${ }^{137} \mathrm{Cs}$ uniformly distributed to a depth of $\mathrm{A}_{\mathrm{p}}$ horizon (20-30 cm of thickness), while in meadow soils $70-80 \%$ of the radionuclide is concentrated within the top Ad horizon ( $9-13 \mathrm{~cm}$ of thickness). These topsoil layer accords with rhizosphere zone, where $>80-90 \%$ of plant roots are concentrated, and from which ${ }^{137} \mathrm{Cs}$ is mostly consumed by vegetation. Total amount of ${ }^{137} \mathrm{Cs}$ root uptake depends on the level of soil radioactive contamination (correlation coefficient 0.61 ). So ${ }^{137} \mathrm{Cs}$ activity in meadow vegetation (103-160 $\mathrm{Bq} / \mathrm{kg}$ ) is generally more than one in agricultural vegetation $(9-92 \mathrm{~Bq} / \mathrm{kg})$. The values of ${ }^{137} \mathrm{Cs}$ transfer factor in the studied ecosystems vary from 0.01 (rape) to 0.20 (wet meadow), that confirms the discrimination of the radionuclide's root uptake. The larger are the volume of roots and their absorbing surface, the higher are the values of transfer factor from soil to plant (correlation coefficients 0.71 and 0.64 respectively). ${ }^{137} \mathrm{Cs}$ translocation from roots to shoots is also determined by biological features of plants. At the same level of soil contamination aboveground parts of meadow herbs accumulate more ${ }^{137} \mathrm{Cs}$ than Gramineae species, and in agrosystems above-ground parts of weeds concentrate more ${ }^{137} \mathrm{Cs}$ than cultivated cereals. Thus, the level of soil radioactive pollution and biological features of plants are determinants in the process of ${ }^{137} \mathrm{Cs}$ root uptake and translocation and should be considered in land use policy.
\end{abstract}

Accepted : 21.11 .2014

Keywords: radioactive contamination, caesium-137, root uptake, transfer factor, Chernobyl accident

(C) 2015 Federation of Eurasian Soil Science Societies. All rights reserved

\section{Introduction}

It has been known that after the Chernobyl accident the combined area of radioactively contaminated agricultural lands in Russia with excess of national standards of radiation safety for ${ }^{137} \mathrm{Cs}$ in soil $\leq 1 \mathrm{Ci} / \mathrm{km}^{2}$ (Rodin and Bazilevich, 1965) comprised about 2.3 million ha and more than 1 million ha of which were contaminated at a level $5-80 \mathrm{Ci} / \mathrm{km}^{2}$, so the Chernobyl accident can be said with assurance as an accident in agriculture (Alexakhin and Korneev, 1991). Nowadays due to extremely long-term consequences of radioactive accidents a significant part of Russian soils still contains ${ }^{137} \mathrm{Cs}$ at a level $5-10$ and more Ci $/ \mathrm{km}^{2}$

\footnotetext{
${ }^{*}$ Corresponding author.

Moscow State University, Soil Science Faculty, Department of Radioecology \& Ecotoxicology, Moscow, 119991 Russia

Tel.: +74959392508

E-mail address: : tapara@mail.ru

ISSN: $2147-4249$
} 
and is assumed will be polluted until the end of the century (Anonymous, 2006; Frissel et al., 2002; Yablokov et al., 2007).

At the same time a high portion of lands contaminated by ${ }^{137} \mathrm{Cs}$ after Chernobyl accident belongs to fertile chernozems, so ones widely continued to be used as croplands in spite of radioactive pollution. Root uptake and translocation of ${ }^{137} \mathrm{Cs}$ from soil into cultural crops or meadow grasses is the key for understanding of general ecological situation and for elaboration of land use policy on such territories.

There are numerous investigations concerning dependence of ${ }^{137} \mathrm{Cs}$ root uptake by different plant species on the level of ${ }^{137} \mathrm{Cs}$ presence in soil, soil properties, climatic conditions, seasonal features. But literature reviews indicate that mostly edible or above-ground parts of plants are taken into account in these studies (Ehlken and Kirchner, 2002; Fujiwara, 2013; Hampton et al., 2005; Staunton et al., 2003; Tamponnet et al., 2008). Even the specialized IAEA's Programme EMRAS (Environmental Modeling for radiation Safety) takes a similar approach to the assessment of ${ }^{137} \mathrm{Cs}$ behaviour in a "soil-plant" system (Fesenko et al., 2007). It is reasonable for practical measures of the control of plant production and soil remediation, but does not provide accurate information of ${ }^{137} \mathrm{Cs}$ root uptake by vegetation in radioactively contaminated terrestrial ecosystems. The more so as hydroponics or soil culture's model experiments demonstrate that ${ }^{137} \mathrm{Cs}$ distribution between roots and shoots is frequently non-uniqueness, and in many case roots accumulate more radionuclide then green parts of plants (Aktar et al., 2009; Brambilla et al., 2002; Golosov et al., 1999; Izrael, 1998; Anonymous, 2009; Smolders and Tsukada, 2011; Takeda et al., 2008; Tamponnet et al., 2008; Walling and Quine, 1990). The detailed studies of the radionuclide behaviour in a "soil-plant" system in the natural conditions of the quasi-equilibrium biogeochemical radionuclide cycle of ${ }^{137} \mathrm{Cs}$ in post-Chernobyl landscapes are fascinating in this connection.

\section{Material and Methods}

\section{Study Area}

With the object to evaluate overall parameters of ${ }^{137} \mathrm{Cs}$ root uptake by grass vegetation on radioactively contaminated lands the study in agricultural and natural meadow ecosystems of post-Chernobyl foreststeppe landscape was conducted. The investigated territory is situated in the central part of Plavsk radioactive hot spot (Figure 1) - the area of pronounced Chernobyl fallout in European Russia (Tula region) where initial level of ${ }^{137} \mathrm{Cs}$ in soils after accident ranged from 5 to $15 \mathrm{Ci} / \mathrm{km}^{2}$ and averaged $\approx 8 \mathrm{Ci} / \mathrm{km}^{2}$ (Greger, 2004). Bomb-derived ${ }^{137}$ Cs fallout in this region during 1949-1963 was negligibly small, so pool of the radionuclide inventory in soils may by completely attribute with Chernobyl accident.

\section{Landscape Characteristics}

The investigated area represents a typical agricultural landscape with arable soils dominating on the watersheds and slopes (altitudes 210-250 m) and natural grassland ecosystems occupying lower parts of slopes and floodplains (altitudes 190-210 m) which are used as pastures and hayfields. The agrosystems with main crops of field rotation (spring barley, potatoes, summer rape, maize) as well as natural ecosystems of dry and wet meadows were selected for the detailed study (Table 1). Total biological productivity of agricultural crops varies between 1 and $4 \mathrm{~kg} / \mathrm{m}^{2}$, the biomass of natural grass ecosystems is about $2 \mathrm{~g} / \mathrm{m}^{2}$, ash content in above- and below-ground parts of vegetation constitutes 5-8\%; all is typical for Russian agricultural and natural ecosystems of forest-steppe zone (Rodin and Bazilevich, 1965).

According to the World Reference Base of soil classification, soil cover of the area is presented mainly by haplic chernozems of watersheds and slopes derived from loess calcareous loams and alluvial meadow soils of floodplains derived from calcareous alluvial loams. They have similar properties - heavy loam texture, bulk density 0.9-1.2 $\mathrm{g} / \mathrm{cm}^{3}$, sum of $\mathrm{A}+\mathrm{AB}$ horizons $\sim 60-80 \mathrm{~cm}$ with $\mathrm{C}_{\text {org }}$ to $5-7 \%$, neutral $\mathrm{pH}_{\mathrm{w}}$.

\section{Soil and Vegetation Sampling}

On each plot vegetation was collected from a fixed space taking into account above- and below-ground biomass (50×50 $\mathrm{cm}^{2}$ and $10 \times 10 \times 30 \mathrm{~cm}^{3}$ correspondently). The quantitative characteristics of vegetation below-ground fraction were estimated after washing from soil particles with a control of adhesion process by visual method and following laboratory analysis of ash content.

Soil samples were collected from the same fixed volume $10 \times 10^{\times 30} \mathrm{~cm}^{3}$ by step $10 \mathrm{~cm}$. The sampled soil profile up to $30 \mathrm{~cm}$ was assumed both as rhizosphere space and current depth of $90 \%{ }^{137} \mathrm{Cs}$ penetration $(3,11)$. Replication on each soil and vegetation site was threefold. 


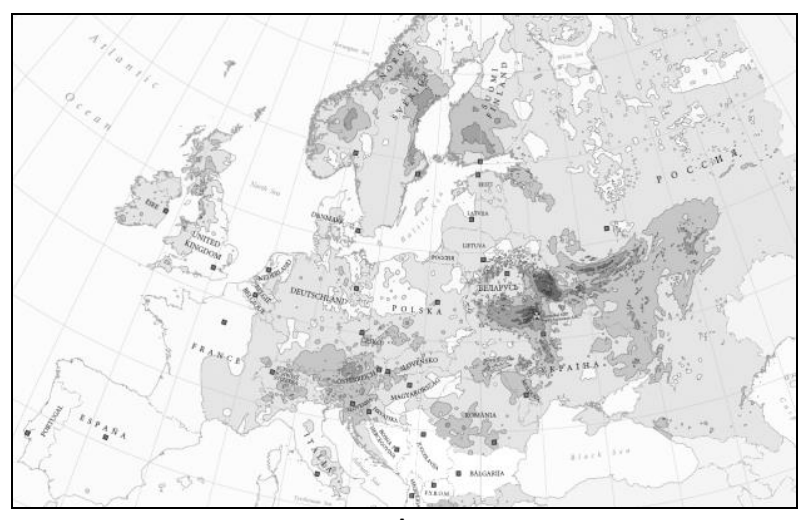

A

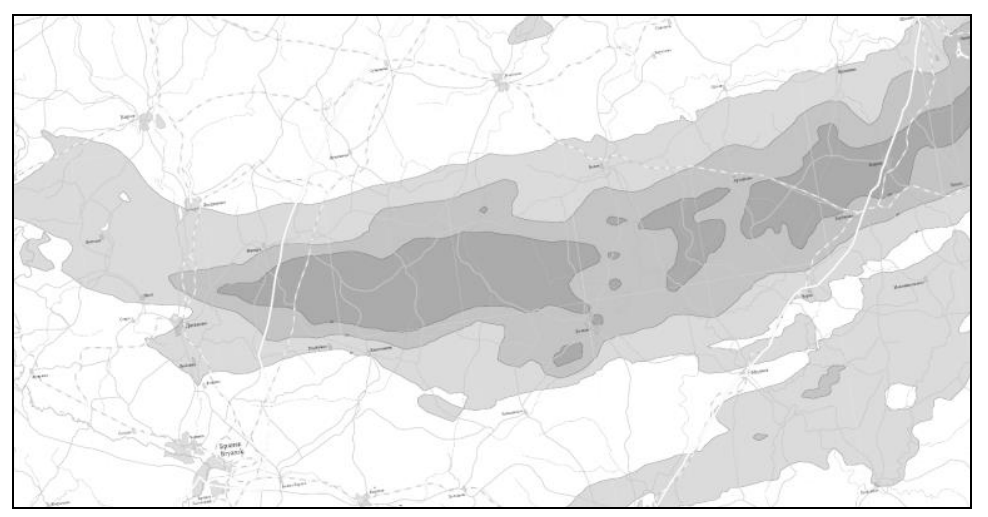

B

Scale 1: 500000

Projection Lambert Azimuthal

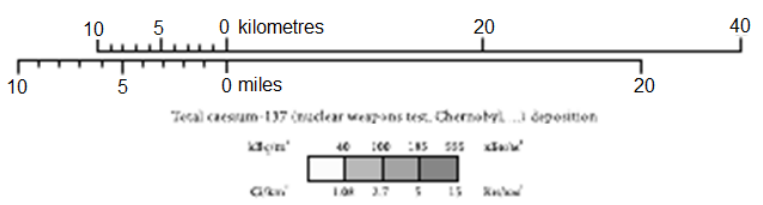

Figure 1. Location of the area under study: A - general location of Plavsk radioactive hot spot and B - location of the investigated area on a map of Europe initial pollution by ${ }^{137} \mathrm{Cs}$ after Chernobyl accident (Izrael, 1998)

Table 1. General characteristic of grass ecosystems under study

\begin{tabular}{|c|c|c|c|c|c|c|}
\hline \multirow{2}{*}{ Charachteristic } & \multicolumn{4}{|c|}{ Agrosystems } & \multicolumn{2}{|c|}{ Natural ecosystems } \\
\hline & barley & maize & rape & potatoes & dry meadow & wet meadow \\
\hline Altitude, $\mathrm{m}$ & 248 & 248 & 245 & 213 & 208 & 194 \\
\hline Relief & & watershed & & $\begin{array}{l}\text { middle part } \\
\text { of slope, } 3-5^{\circ}\end{array}$ & $\begin{array}{l}\text { lower part of } \\
\text { slope, } 7-10^{\circ}\end{array}$ & floodplain \\
\hline Landscape & & eluvial & & trans-acc & mulative & accumulative \\
\hline Parents rocks & & & ess calcal & us loams & & alluvial loams \\
\hline Land use & & & e lands & & pasture & hayfield \\
\hline Soil & & arable ha & ic cherno & & $\begin{array}{c}\text { haplic } \\
\text { chernozem }\end{array}$ & $\begin{array}{l}\text { calcareous } \\
\text { alluvial }\end{array}$ \\
\hline - humus, $\%$ & 6.5 & 6.8 & 6.7 & 6.3 & 5.2 & 5.8 \\
\hline$-\mathrm{pH}_{\mathrm{w}}$ & 6.6 & 6.5 & 6.5 & 6.9 & 7.1 & 6.9 \\
\hline${ }^{-} \mathrm{g} / \mathrm{cm}^{3}$ bulk & 1.05 & 0.98 & 1.21 & 0.92 & 1.16 & 1.16 \\
\hline Vegetation & & Aral crops & ith admix & weeds & $\begin{array}{l}\text { grass-herb } \\
\text { meadow }\end{array}$ & $\begin{array}{l}\text { herb-grass } \\
\text { meadow }\end{array}$ \\
\hline - total biomass, $\mathrm{kg} / \mathrm{m}^{2}$ & 2,2 & 3,9 & 1,0 & 1,9 & 1.9 & 2.2 \\
\hline - above-ground biomass, $\mathrm{kg} / \mathrm{m}^{2}$ & 1,5 & 1,4 & 0,4 & 1,1 & 0.2 & 0.3 \\
\hline - below-ground biomass, $\mathrm{kg} / \mathrm{m}^{2}$ & 0,7 & 2,5 & 0,6 & 0,8 & 1.7 & 1.9 \\
\hline $\begin{array}{l}\text { - above-ground / below-ground } \\
\text { biomass ratio, } \%\end{array}$ & $67 / 33$ & 35 / 65 & $41 / 59$ & $56 / 44$ & $8 / 92$ & 13 / 87 \\
\hline - ash content in total biomass, $\%$ & 5.4 & 7.3 & 5.3 & 5.2 & 8.4 & 7.0 \\
\hline $\begin{array}{l}\text { - ash content in above-ground } \\
\text { biomass, } \%\end{array}$ & 5.4 & 7.6 & 8.1 & 4.9 & 7.9 & 8.4 \\
\hline $\begin{array}{l}\text { - ash content in below-ground } \\
\text { biomass, } \%\end{array}$ & 5.4 & 7.5 & 3.3 & 5.5 & 8.5 & 6.8 \\
\hline
\end{tabular}

\section{Laboratory Analysis}

Subsequent laboratory treatment of soil and vegetation samples involved oven-drying at $105^{\circ} \mathrm{C}$, grinding, sieving to particles $<2 \mathrm{~mm}$ and homogenization of samples for gamma spectrometric and other analysis. The ${ }^{137} \mathrm{Cs}$ activity was measured with counting time 0.5 hour at $661.66 \mathrm{keV}$, using a scintilla gamma-ray NaI detector. Maximum relative error of ${ }^{137} \mathrm{Cs}$ activity determination reached $10-20 \%$. 
Vegetation biomass, ash content and bulk density of soils were estimated by weight method. Root volume and absorbing surface of roots were deduced by displacing of water and quantitative absorption of methylene blue. Soil chemical analysis $\left(\mathrm{C}_{\mathrm{org}}, \mathrm{pH}_{\mathrm{w}}\right)$ were conducted by standard methods.

\section{Results and Discussion}

\section{${ }^{137}$ Cs Activity in Soil and Vegetation}

Current values of ${ }^{137} \mathrm{Cs}$ activity in the upper 30 -cm layer of the investigated soils of Plavsk radioactive hot spot exceed $450 \mathrm{~Bq} / \mathrm{kg}$ (Table 2), that confirms the long-term consequences of ${ }^{137} \mathrm{Cs}$ contamination in terrestrial ecosystems. Parameters of the radionuclide's accumulation in soils of meadow ecosystems are significantly higher than ones in arable chernozems. This indicates a pronounced redistribution of the radionuclide within the river catchments of forest-steppe zone, leading to an increase in the density of radioactive contamination in geochemically subordinate positions. A such data is mainly associated with water and tillage erosion transport of ${ }^{137}$ Cs developing on cultivated hill slopes (Belyaev et al., 2013; Greger, 2004; Yablokov et al., 2007), but advanced surface of meadow herbs and grasses in comparison with rare vegetation of agrosystems in the course of April-May Chernobyl fallout in 1986 probably fulfilled a role of additional biological barrier for ${ }^{137} \mathrm{Cs}$ assertion in "soil-plant" system of natural grass ecosystems.

Table 2. Mean ${ }^{137} \mathrm{Cs}$ activity in soil and vegetation of investigated grass ecosystems and TF values

\begin{tabular}{|c|c|c|c|c|c|c|}
\hline \multirow{2}{*}{ Charachteristic } & \multicolumn{4}{|c|}{ Agrosystems } & \multicolumn{2}{|c|}{ Natural ecosystems } \\
\hline & barley & maize & rape & potatoes & dry meadow & wet meadow \\
\hline \multicolumn{7}{|c|}{${ }^{137} \mathrm{Cs}$ activity, $\mathrm{Bq} / \mathrm{kg}$} \\
\hline Soil & 486 & 459 & 494 & 674 & 712 & 621 \\
\hline Total biomass & 30,7 & 58,0 & 4,8 & 37,0 & 73,0 & 120,4 \\
\hline Above-ground biomass & 6,6 & 6,0 & 6,6 & 44,7 & 25,4 & 26,0 \\
\hline Below-ground biomass & 79,2 & 85,7 & 2,4 & 31,8 & 77,5 & 134,1 \\
\hline \multicolumn{7}{|c|}{ Transfer factor } \\
\hline $\mathrm{TF}_{\text {tot }}{ }^{*}$ & 0.06 & 0.13 & 0.01 & 0.05 & 0.10 & 0.19 \\
\hline $\mathrm{TF}_{\mathrm{ag}}{ }^{* *}$ & 0.01 & 0.01 & 0.01 & 0.07 & 0.04 & 0.04 \\
\hline $\mathrm{TFbg}^{* * *}$ & 0.16 & 0.19 & 0.01 & 0.05 & 0.11 & 0.22 \\
\hline
\end{tabular}

The values of ${ }^{137} \mathrm{Cs}$ activity in vegetation is an order less than in soils. Meadow plants, especially vegetation of wet meadow, growing on more polluted soils are characterized by relatively higher ${ }^{137} \mathrm{Cs}$ activities, and maize as a whole is slightly enriched by ${ }^{137} \mathrm{Cs}$ among other investigated cultural crops. Generally total accumulation of ${ }^{137} \mathrm{Cs}$ in vegetation somewhat depends on the level of soil radioactive contamination (Figure $2 \mathrm{~A})$. But this correlation is more distinctly pronounced in a pair " ${ }^{137} \mathrm{Cs}$ in soil $-{ }^{137} \mathrm{Cs}$ in above-ground biomass" and appears rather slightly in a pair " $137 \mathrm{Cs}$ in soil $-{ }^{137} \mathrm{Cs}$ in below-ground biomass" (Figure $2 \mathrm{~B}$ ).

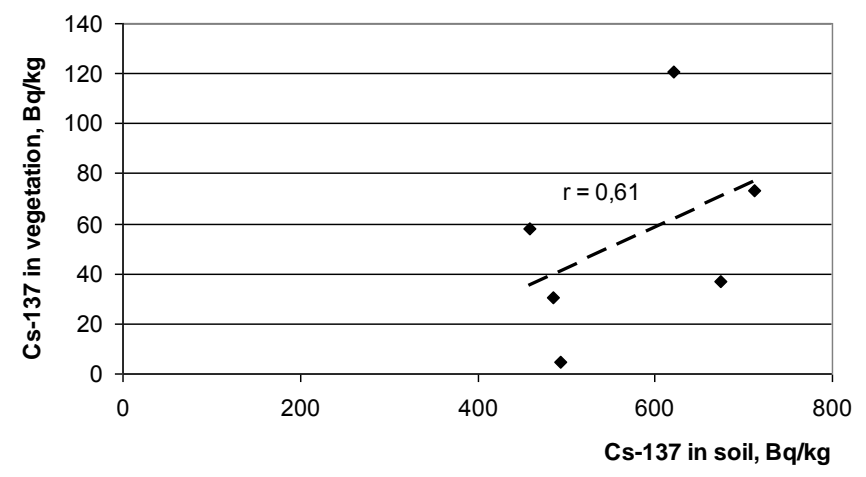

(A)

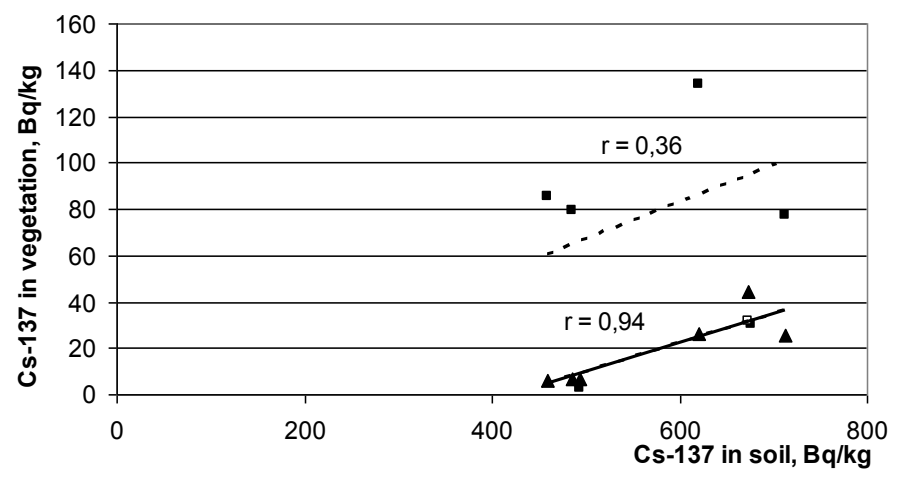

$\Delta$ Above-ground biomass - Below-ground biomass a Below-groun biomass of potatoes

(B)

Figure 2. Relationship between averaged ${ }^{137} \mathrm{Cs}$ activity $(\mathrm{Bq} / \mathrm{kg})$ in vegetation and soil of investigated grass ecosystems: A - total biomass, $\mathrm{B}$ - above-ground and below-ground biomass 
The other reason of the relatively increased ${ }^{137} \mathrm{Cs}$ activity in natural meadow vegetation may be the predominance of perennial herbs and grasses which may gradually accumulate ${ }^{137} \mathrm{Cs}$ during lifetime whereas agrosystems consist of annual crops with a short biogeochemical cycle of nutrients.

But the most striking feature of ${ }^{137} \mathrm{Cs}$ accumulation in vegetation is a significant difference in the radionuclide's content between above-ground and below-ground fractions of plants. The values of ${ }^{137} \mathrm{Cs}$ specific activity in below-ground biomass (mainly roots) are 2-5 times greater than ones in green parts of plants except rape having stem root system and potatoes where the distribution of ${ }^{137} \mathrm{Cs}$ over total biomass is relatively uniform (but below-ground fraction of potatoes mainly is represented by modified shoots, but no roots).

The depositing role of the below-ground vegetation fractions regarding ${ }^{137} \mathrm{Cs}$ is even more pronounced in the event of biomass inventories scan. Since 33-65\% of total biomass in barley and maize agrosystems and 87 $92 \%$ of total biomass in meadows is concentrated underground, then more than $86-98 \%$ of ${ }^{137} \mathrm{Cs}$ inventories are confined to the below-ground biomass.

\section{Biological Features of ${ }^{137}$ Cs Root Uptake and Translocation into Shoots}

The absence of direct proportion between ${ }^{137} \mathrm{Cs}$ activity in soil and in below-ground biomass demonstrates barrier function of roots in ${ }^{137} \mathrm{Cs}$ penetration into plant tissues and the importance of revealing the biological features of different species and families of plants influenced on this process.

To estimate the biological features of ${ }^{137} \mathrm{Cs}$ root uptake unaffected by the level of soil radioactive contamination transfer factor values (TF, the ratio of the specific ${ }^{137} \mathrm{Cs}$ activity in the plant tissue and in soil) were calculated (Table 2). Total values of ${ }^{137} \mathrm{Cs} \mathrm{TF}_{\text {tot }}$ in the studied grass ecosystems vary from 0.01 (rape) to 0.20 (wet meadow), that confirms the common discrimination of the radionuclide root uptake resulted from ${ }^{137}$ Cs xenobiotic nature.

At the same time there is a noticeable difference in ${ }^{137} \mathrm{Cs} \mathrm{TF}_{\text {tot }}$ as well as in $\mathrm{TF}_{\mathrm{bg}}$ for plant tissues of various ecosystems. The highest $\mathrm{TF}_{\mathrm{bg}}$ values in below-ground fraction are typical for vegetation with dominant Gramineae family species (barley, maize, herb-grass meadows) having fibrous root system. And such amounts are typical for cereals whether cultural or wild, annual or perennial. The lowest $\mathrm{TF}_{\mathrm{bg}}$ value in below-ground fraction is characterized for rape agrosystem having stem root system.

There is no doubt that accumulation of ${ }^{137} \mathrm{Cs}$ in vegetation is connected with the intensity of the radionuclide root uptake. A comparison of modern soil profile distribution of ${ }^{137} \mathrm{Cs}$, root volume and root absorbing surface values shows very similar characteristics (Figure 3) with correlation coefficients 0.71 and 0.64 respectively. So root systems of grass vegetation not only develop within the most radioactively contaminated soil layers, but also can serve as disseminators of ${ }^{137} \mathrm{Cs}$ penetration in a soil profile. In the arable chernozems ${ }^{137} \mathrm{Cs}$ uniformly distributed to a depth of $A_{p}$ horizon (20-30 cm of thickness), while in meadow soils $70-80 \%$ of the radionuclide is concentrated within the top $A_{d}$ horizon ( $9-13 \mathrm{~cm}$ of thickness).

Process of ${ }^{137} \mathrm{Cs}$ translocation from roots to shoots is also determined by biological features of plants. But whereas root uptake of ${ }^{137} \mathrm{Cs}$ for the most parts increases with increasing in below-ground biomass (correlation coefficient 0.68 ), ${ }^{137} \mathrm{Cs}$ activities in above-ground parts of vegetation are nearly invariant from above-ground biomass or from the ratio between above-ground biomass and below-ground biomass. So transfer of ${ }^{137} \mathrm{Cs}$ from roots to shoots still further depends on biological depends on the biological properties of plant species, and not merely on the rate of the above-ground biomass growth. The most significant discrimination of ${ }^{137} \mathrm{Cs}$ translocation into green parts is expressed in cultural cereals agrosystems where $\mathrm{TF}_{\mathrm{ag}}$ in above-ground fraction are 12-14 times less then ones in below-ground fraction. In herb-grass meadow plant associations the ratio of $\mathrm{TF}_{\mathrm{bg}}$ and $\mathrm{TF}_{\mathrm{ag}}$ values is $3-5$. So there is additional biological barrier for ${ }^{137} \mathrm{Cs}$ between roots and shoots in the majority of plant species. On the other hand, in rape and potatoes agrosystems $\mathrm{TF}$ values for ${ }^{137} \mathrm{Cs}$ in above- and below-ground parts are little different, that may be depend on stem root system of Brassicaceae family in the first case, whereas in potatoes agrosystem similarity of $\mathrm{TF}_{\mathrm{ag}}$ and $\mathrm{TF}_{\mathrm{bg}}$ values may be determined by the peculiarity of tubers tissues having analogy to shoot tissues. 
A.

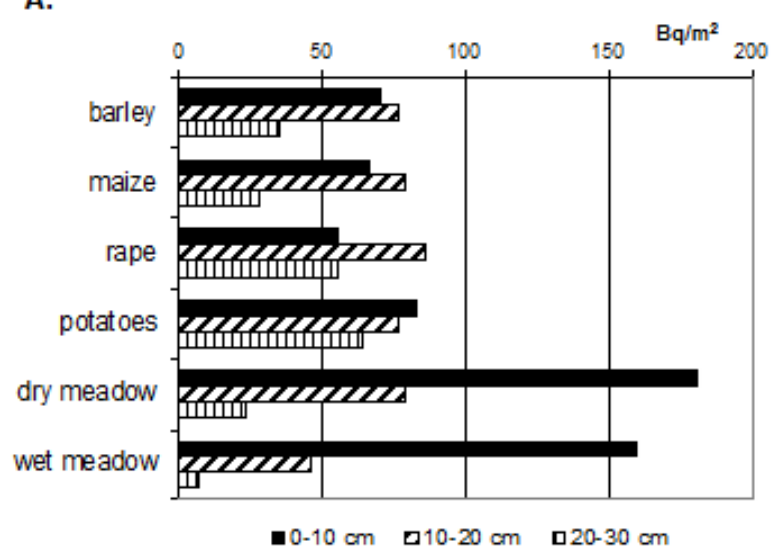

B.

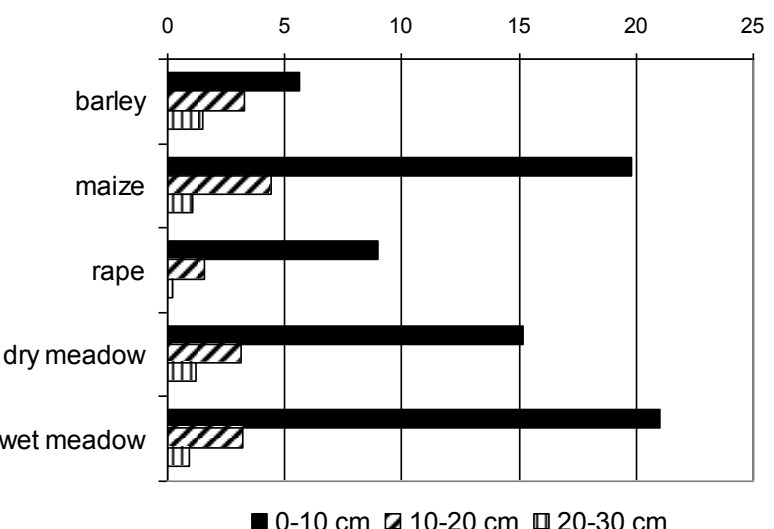

C. $\mathrm{m}^{2} / \mathrm{cm}^{3}$ of root volume

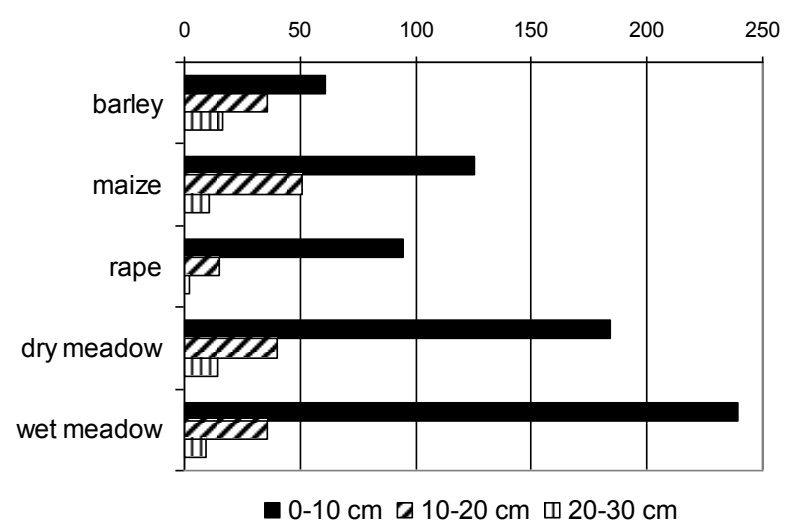

Figure 3. Soil profile distribution. A - inventories of ${ }^{137} \mathrm{Cs}$ in soil $\left(\mathrm{Bq} / \mathrm{m}^{2}\right)$;

$B$ - root volume $\left(\mathrm{m}^{3} / \mathrm{m}^{2}\right.$ of soil); C - root absorbing surface $\left(\mathrm{m}^{2} / \mathrm{cm}^{3}\right.$ of root volume)

The importance of plant species features in the process of ${ }^{137} \mathrm{Cs}$ translocation over below- and above-ground parts may also be noticed under comparison of $\mathrm{TF}_{\mathrm{ag}}$ values for different biological groups of plants growing at the same level of soil radioactive contamination (Figure 4). Above-ground parts of meadow herbs universally accumulate more ${ }^{137} \mathrm{Cs}$ than Gramineae species, and above-ground parts of weeds (bindweed, Convolvulaceae family, in barley agrosystem and quinoa, Chenopodiaceae family, in maize agrosystem) concentrate more ${ }^{137} \mathrm{Cs}$ than corresponding cultivated cereals.

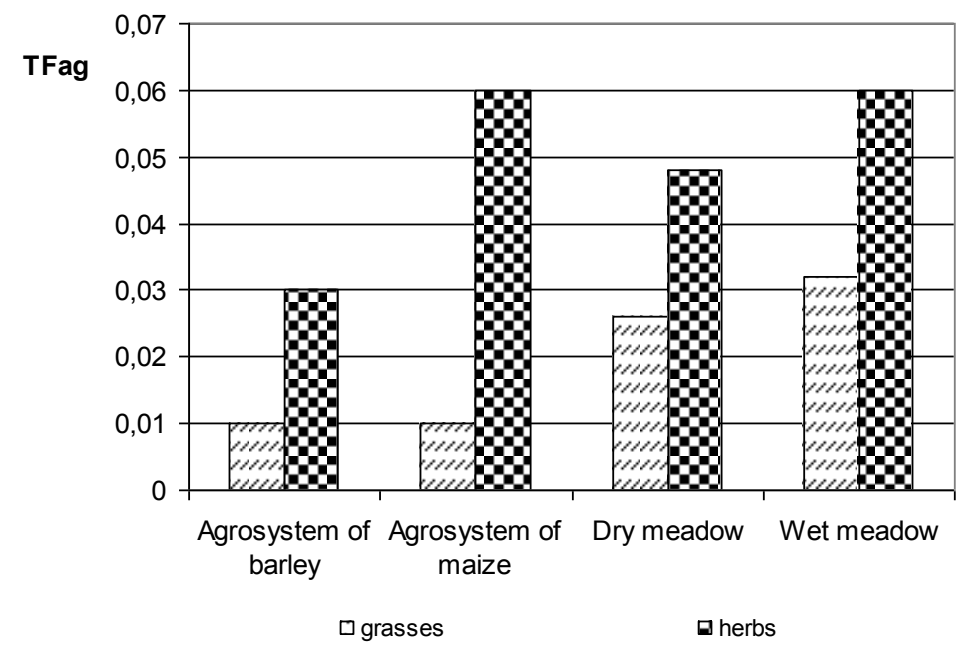

Figure 4. Transfer factor of ${ }^{137} \mathrm{Cs}$ for above-ground biomass of plant species from different biological groups 


\section{Inventories of ${ }^{137} \mathrm{Cs}$ in Grass Ecosystems of Plavsk Hot Spot Post-Chernobyl Landscape}

The final assessment of the ${ }^{137} \mathrm{Cs}$ distribution of in the "soil-plant" system of grass ecosystems of Plavsk hot spot has revealed that $99.9 \%$ and more of total ${ }^{137} \mathrm{Cs}$ inventory is localized in soil (Table 3). Annual inventory of ${ }^{137} \mathrm{Cs}$ in vegetation is very small; especially the ${ }^{137} \mathrm{Cs}$ yield alienation in agrosystems is minor. In such conditions of strong ${ }^{137} \mathrm{Cs}$ fixation by soils and insignificant radionuclid's root uptake by plants there is a possibility to obtain ecologically acceptable agricultural production on contaminated post-Chernobyl lands in the remote period after the accident.

Table 3. Inventories of ${ }^{137} \mathrm{Cs}$ in "soil-plant" system of investigated grass ecosystems

\begin{tabular}{|c|c|c|c|c|c|}
\hline \multirow{2}{*}{$\begin{array}{l}\text { Grass } \\
\text { ecosystem }\end{array}$} & \multirow{2}{*}{$\begin{array}{l}\text { Total inventories of }{ }^{137} \mathrm{Cs} \text { in } \\
\text { "soil-plant" system, } \mathrm{Ci} / \mathrm{km}^{2}\end{array}$} & \multicolumn{2}{|c|}{ Inventories of ${ }^{137} \mathrm{Cs}$ in soil } & \multicolumn{2}{|c|}{ Inventories of ${ }^{137} \mathrm{Cs}$ in vegetation } \\
\hline & & $\mathrm{Ci} / \mathrm{km}^{2}$ & $\%$ & $\mathrm{Ci} / \mathrm{km}^{2}$ & $\%$ \\
\hline \multicolumn{6}{|c|}{ Agrosystems } \\
\hline barley & 4,908 & 4,906 & 99,96 & 0,002 & 0,04 \\
\hline maize & 4,700 & 4,694 & 99,87 & 0,006 & 0,13 \\
\hline rape & 5,303 & 5,302 & 99,99 & 0,001 & 0,01 \\
\hline potatoes & 6,012 & 6,011 & 99,98 & 0,001 & 0,02 \\
\hline \multicolumn{6}{|c|}{ Natural ecosystems } \\
\hline dry meadow & 7,631 & 7,627 & 99,95 & 0,004 & 0,05 \\
\hline wet meadow & 5,766 & 5,759 & 99,87 & 0,007 & 0,03 \\
\hline
\end{tabular}

\section{Conclusion}

- Soil contamination by ${ }^{137} \mathrm{Cs}$ in natural and agricultural grass ecosystems of the post-Chernobyl Plavsk hot spot area is currently being evaluated as $5-8 \mathrm{Ci} / \mathrm{km}^{2}$. Soils of geochemically subordinate natural meadow landscapes accumulate $\sim 25 \%$ more the radionuclide than arable soils of eluvial landscapes.

- Modern parameters of ${ }^{137} \mathrm{Cs}$ root uptake are characterized by low intensity that reveals the discrimination in ${ }^{137} \mathrm{Cs}$ transfer from contaminated soil into grass vegetation. $99.9 \%$ and more of total ${ }^{137} \mathrm{Cs}$ inventory is strongly fixed in soil. So there is a possibility to obtain ecologically acceptable agricultural production on contaminated post-Chernobyl lands in the remote period after the accident.

- ${ }^{137} \mathrm{Cs}$ activity in below-ground biomass in so doing may be 2-5 times greater than in the above-ground biomass, which requires quantitative account of ${ }^{137} \mathrm{Cs}$ accumulation not only in eatable, as a rule green parts, but also in below-ground parts especially for the plant species from Gramineae family.

- There is a close connection between distribution of ${ }^{137} \mathrm{Cs}$, root volume and root absorbing surface values in soil profile. So roots of grass vegetation not only develop within the most radioactively contaminated soil layers, but also can serve as disseminators of ${ }^{137} \mathrm{Cs}$ penetration into the depth. In the arable chernozems ${ }^{137} \mathrm{Cs}$ uniformly distributed to a depth of $\mathrm{A}_{\mathrm{p}}$ horizon (20-30 cm of thickness), while in meadow soils $70-80 \%$ of the radionuclide is concentrated within the top $A_{d}$ horizon $(9-13 \mathrm{~cm}$ of thickness).

- The major differences in the ${ }^{137} \mathrm{Cs}$ root uptake and further translocation into above-ground biomass are closely related to the level of soil radioactive pollution and biological features of plant species and families that should be considered in land use policy.

\section{Acknowledgements}

The study is conducted with the support from the Russian Foundation of Basic Research (RFBR), project no. 14-05-00903A. Besides, the authors are grateful for the valuable and friendly assistance in the field investigations and sampling Professor V.N.Golosov (Geography Faculty of Moscow State Lomonosov University).

\section{References}

Aktar, M., Ullah, S.M., Begum, A., Mollah, S., Mamun, Sh., 2009. Effect of ${ }^{137}$ Cs on the transfer of nutrient elements and on growth of lettuce (Lactuca sativa). Journal of Innovation and Development Strategy 3(3): 18-30.

Alexakhin, R.M., Korneev, N.A., 1991. Agricultural Radioecology. Ecology, Moscow (in Russian).

Anonymous, 2006. Environmental Consequences of the Chernobyl Accident and their Remediation: Twenty Years of Experience, 2006. Report of the UN Chernobyl Forum Expert Group "Environment". Radiological Assessment Reports Series 8. Vienna. 
Anonymous, 2009. Norms of radiation safety (NRS 99/2009), 2009. Moscow (in Russian).

Belyaev, V.R., Golosov, V.N., Markelov, M.V., Evrard, O., Ivanova, N.N., Paramonova, T.A., Shamshurina, E.N., 2013. Assessment of the recent sediment deposition rates on the Plava River floodplain (Central European Russia) using the ${ }^{137}$ Cs radionuclide tracer. Hydrological Processes 27 (6): 807-821.

Brambilla, M., Fortunati, P., Carini, F., 2002. Foliar and root uptake of ${ }^{134} \mathrm{Cs}$, ${ }^{85} \mathrm{Sr}$ and ${ }^{65} \mathrm{Zn}$ in prosessing tomato plants (Lycorersicon esculentum Mill.). Journal of Environmental Radioactivity 60: 351-363.

Ehlken, S., Kirchner, G., 2002. Environmental processes affecting plant root uptake of radioactive trace elements and variability of transfer factor data: a review. J. Environ. Radioact. 58, 97-112.

Fesenko, S., Alexakhin, R.M., Balonov, M.I., Bogdevitch, I.M., Howard, B.J., Kashparov, V.A., Sanzharova, N.I., Panov, A.V., Voigt, G., Zhuchenka, Y.M., 2007. An extended critical review of twenty years of countermeasures used in agriculture after the Chernobyl accident. Science of the Total Environment 383(1-3): 1-24.

Frissel, M.J., Debb, D.L., Fathonyc, M., Lin, Y.M., Mollah, A.S., Ngo, N.T., Othman, I., Robison, W.L., Skarlow-Alekxion, V., Topcuoglu, S., Twining, J.R., Uchida, S., Wasserman, M.A., 2002. Generic values for soil-to-plant transfer factors of radiocesium. Journal of Environmental Radioactivity 58: 113-128.

Fujiwara, T., 2013. Cesium Uptake in Rice: Possible Transporter, Distribution and Variation. In: Nakanishi T. M., Tanoi K. (Eds.), Agricultural Implications of the Fukushima Nuclear Accident. Tokyo, Heidelberg, New York, Dordrecht, London. 29-36.

Golosov, V. N., Panin, A. V., Markelov, M.V., 1999. Chernobyl ${ }^{137}$ Cs redistribution in the small basin of the Lokna River, Central Russia. Physics \& Chemistry of the Earth (A) 24 (10): 881-885.

Greger, M., 2004. Uptake of nuclides by plants. Stockholm University, Sweden, Technical Report TR-04-14. Available at. http://www.skb.se/upload/publications/pdf/TR-04-14.pdf).

Hampton, C.R., Broadley, M.R., White, P.J., 2005. Short review: The mechanisms of radiocaesium uptake by Arabidopsis roots. Nukleonika 50: 3-8.

Izrael Yu. A. (ed.), 1998. Atlas of radionuclide contamination of European parts of Russia, Belorussia and the Ukraine. IGKE Rosgidromet, Roskartographiya, Moscow (in Russian).

Ladeyn, I., Plassard, C., Staunton, S., 2008. Mycorrhizal association of maritime pine, Pinus pinaster, with Rhizopogon roseolus has contrasting effects on the uptake from soil and root-to-shoot transfer of ${ }^{137} \mathrm{Cs},{ }^{85} \mathrm{Sr}$ and ${ }^{95 \mathrm{~m} T c}$. Journal of Environmental Radioactivity 99: 853-863.

Rodin, L.E., Bazilevich, N.I., 1965. Production and Mineral Cycling In Terrestrial Vegetation. Nauka, Moscow-Leningrad (in Russian).

Show, G., Bell, J.N.B., 1989. The Kinetics of Caesium Absorbtion by Roots of Winter Wheat and the Possible Consequences for the Derivation of soil-to-Plant transfer Factors for Radiocaesium. Journal of Environmental Radioactivity 10: 213-231.

Smolders, E., Tsukada, H., 2011. The Transfer of Radiocesium from Soil to Plants: Mechanisms, Data, and Perspectives for Potential Countermeasures in Japan. Integrated Environmental Assessment and Management 7 (3): 379-381.

Staunton, S., Hinsinger, P., Guivarch, A., Brechignac, F., 2003. Root uptake and translocation of radiocaesium from agricultural soils by various plant species. Plant and Soil 254: 443-455.

Takeda, A., Tsukada, H., Takaku, Yu.,Akata, N., Hisamatsu, Sh., 2008. Plant induced changes in concentrations of caesium, strontium and uranium in soil solution with reference to major ions and dissolved organic matter. Journal of Environmental Radioactivity 99: 900-911.

Tamponnet, C., Martin-Garin, A., Gonze ,M.A., Parekh, N., Vallejo, R., Sauras-Year, T., Casadesus, J., Plassard, S., Staunton, S., Norden, M., Avila, R., Shaw, G., 2008. An overwie of BORIS: Bioavailability of Radionuclides in Soils. Journal of Environmental Radioactivity 99: 820-830.

Waegeneers, N., Smolders, E., Merckx, R., 2005. Modelling ${ }^{137}$ Cs uptake in plants from undisturbed soil monoliths. Journal of Environmental Radioactivity 81: 187-199.

Walling, D.E., Quine, T.A., 1990. Calibration of caesium-137 measurements to provide quantitative erosion rate data. Land Degradation and Rehabilitation 2: 161-175.

Yablokov, A.V., Nesterenko, V.B., Nesterenko, A.V., 2007. Chernobyl: the consequences of the accident for human and environment. S.-Petersburg (in Russian). 